\title{
The gendered division of housework and fertility intention in Turkey
}

Serap Kavas

Correspondence: serapkavas@gmail. com

Istanbul, Turkey

\begin{abstract}
It is increasingly acknowledged that an equal sharing of domestic labour in a household influences women's childbearing behavior in a positive way. Despite the growing literature on this association, there is little research exploring this phenomenon in the Middle Eastern setting. Using intensive interviews with women $(n=32)$, I examine how the division of domestic labour is connected to women's intention to continue childbearing in Turkey, an understudied region. The study finds that husbands' housework share is positively related to women's fertility intention for an additional child in Turkey. The gender revolution framework offers an explanation for fertility and gender relationship in Turkey; however, the fact that only a small number of sampled women enjoyed domestic equality and greater desire to continue childbearing suggests that the gender revolution is just evolving in this environment.
\end{abstract}

Keywords: Division of housework, Domestic gender equality, Gender revolution framework, Fertility intention, Qualitative method

In the past several decades, there have been dramatic changes in women's status with increasing numbers of women achieving a high level of education and participating in the labour force across industrialized countries (e.g., Mills et al., 2008). However, except for a few Nordic countries, it is still difficult to talk about a complete gender revolution that includes egalitarian relationships in the domestic sphere. While there is a continuous increase in women's labour force participation, their participation in unpaid work has not changed correspondingly, and there are only modest changes in men's share of domestic tasks (Bianchi, Milkie, Sayer, \& Robinson, 2000; Brines, 1994; Gershuny, 2000; Hochschild \& Machung, 1989), manifesting the relevance of the notion of the "stalled gender revolution" that persists today (Hochschild \& Machung, 1989).

Recently, studies have documented a connection between gender equality in the domestic sphere and its impact on fertility. This strand of research shows that in families where women do the majority of the housework, the likelihood of progression to higher order births is rather low (e.g., Aassve, Fuochi, Mencarini, \& Mendola, 2015; Miettinen, Lassi, \& Rotkirch, 2015). On the other hand, in households characterized by a more egalitarian division of housework where husbands increasingly share domestic responsibilities, fertility tends to increase (Aassve et al., 2015; Cooke, 2009; Duvander \& Andersson, 2006; Esping-Andersen, 2009; Kan \& Hertog, 2017; McDonald, 2000a, 2000b; Oláh, 2003; Puur, Oláh, Tazi-Preve, \& Dorbritz, 2008; Torr \& Short, 2004).

(c) The Author(s). 2019 Open Access This article is distributed under the terms of the Creative Commons Attribution 4.0 International License (http://creativecommons.org/licenses/by/4.0/), which permits unrestricted use, distribution, and reproduction in any medium, provided you give appropriate credit to the original author(s) and the source, provide a link to the Creative Commons license, and indicate if changes were made. 
While there is ample evidence suggesting a positive correlation between the equal sharing of domestic labour in a household and fertility rates, recent research reports more complicated results with substantial variations across societies (e.g. Brinton, Bueno, Oláh, \& Hellum, 2018; Cavalli \& Rosina, 2011; Freeman, Xiaohong, Ping, Wenshan, \& Gietel-Basten, 2018; Kan \& Hertog, 2017; Mills et al., 2008; Yang, 2017; Yoon, 2017). While a great deal of research focuses on industrialized countries in the West, there are few studies testing this association in a non-Western setting, with those studies focusing mainly on East Asian countries (e.g., Freeman et al., 2018; Kan \& Hertog, 2017; Kim, 2017; Nagase \& Brinton, 2017; Yang, 2017; Yoon, 2017). No doubt, increasing the regional and cultural diversity of the literature is useful in understanding various dynamics affecting the link between the division of domestic labour and fertility trends. Towards this end, this article explores whether there is a connection between the gendered division of labour in the family and reproductive choice in a Middle Eastern setting; Turkey, a country little-studied, thereby providing a novel contribution to a better understanding of the country itself. In particular, I ask how each partner's participation in domestic labour and childcare influences women's fertility intention for an additional child in Turkey.

The study draws on qualitative data from 32 women obtained through intensive interviews carried out between June 2015 and January 2016. The women who participated in this study are all mothers with at least one child and, except for two, are all married. The qualitative data analyzed in this study provides contextual and detailed information on women's perception of the division of labour in their family and their decision-making process. As research demonstrates, qualitative approaches offer the opportunity to "hear individuals' interpretations of their own situation and the conditions they think will help or hinder the ability to reach their goals" (Brinton et al., 2018, p. 304). Moreover, for the last two decades, the importance of the use of qualitative approaches in demography has been increasingly acknowledged as they "complement" quantitative methods, particularly in research about fertility-"a sensitive and complicated domain not easily approached through survey methods" (Randall \& Koppenhaver, 2004, p. 58). Therefore, this study aims to contribute to the literature by exploring a complex issue of reproductive decision-making using micro-level data and analysis.

In this paper, the theoretical framework on the connection between gendered role sharing in the domestic sphere and fertility rates is laid out. Then it will discuss gender roles, the division of labour, and fertility patterns in Turkey. Finally, the remaining sections are devoted to the research design and qualitative findings.

\section{Theoretical background and literature review}

\section{Neoclassical economic approach}

Most of the research addressing the gendered division of labour in the family sphere and fertility refers to widely used perspectives that include neoclassical economic theory (Becker, 1981, 1985) and the gender revolution framework (Goldscheider, Bernhart, \& Lappegård, 2015). According to neoclassical economic theory, the division of labour in the family is an end result of the specialization of men and women in their human capital to achieve efficiency in their household. Drawing on their "intrinsically different comparative advantage" (Becker, 1985, p. 41), individuals are motivated to contribute to their 
specified roles, which, for the most part, results in women taking up unpaid work since they are the primary caregiver, have less earning power, and lower status. On the other hand, men take up paid work because of their high earning power and higher status. According to this theory, while the notion of comparative advantage usually seems to yield a gendered division of labour, it is independent of sex and draws on the relative sources partners have. It is the rational allocation of time and investments between spouses which ultimately determines "the energy" spouses spend differentially in housework and market activities (Becker, 1985, p. 43).

With the presence of children, this consensus-specialization becomes more intense with men and women finding the traditional division of labour more efficient in economic terms (Dribe \& Stanfors, 2009). Also, with young children in the family, the total work men and women perform increases since having a young child increases the housework hours performed. As empirical studies report, men's labour market commitment increases while women do a larger share of housework (Bianchi et al., 2000; Presser, 1994; Sanchez \& Thomson, 1997).

\section{Gender perspectives, the theory of gender revolution and fertility}

The neoclassical economic theory and its consensus-specialization model have been criticized by feminist scholars who argue that it is naive to think of the division of housework independent of gender norms that are formed through partners' rational choices (e.g., Bianchi et al., 2000; Brines, 1994). In high-income and low-fertility settings, in particular, housework, as these scholars state, is a "symbolic enactment of gender relations" in marriage in that partners structure household labour according to what they have learned about gender-appropriate behaviors for husband and wife (Bianchi et al., 2000: 194). As Brines (1994) states, one piece of evidence for the strong drive for the adherence to gender norms in the household manifests itself when couples break gender norms (e.g., breadwinner wives and dependent husbands). Couples in such situations may resort to the gendered division of labour even more energetically. As research shows, dependent husbands whose gender role is threatened increasingly retreat from domestic labour (Hochschild \& Machung, 1989).

The relevance of gender roles becomes more evident with the presence of children in the household. When they become parents, men and women adhere to cultural norms that define a "good mother and father" and "engage in doing parenthood" (Singley \& Hynes, 2005, p. 380). In high-income contexts, couples increasingly adopt a traditional division of labour with women, for the most part, undertaking a greater share of domestic burden as they become mothers (Presser, 1994; Sanchez \& Thomson, 1997).

Moreover, in addition to individual and cultural practices, gender also shapes macro practices through, for example, exerting influence on governments' workfamily policies. In their qualitative work, Singley and Hynes (2005) find that gendered norms prescribe fathering and mothering in relation to work-family policies, which in turn, reinforces the gender gap in the labour market. Thus, when they want to return to work after becoming a mother, women find themselves in more disadvantaged market conditions with, for example, short-term maternal leave and part-time work with low pay and few benefits. 
Recently, another theoretical framework, the gender revolution theory, offered explanations about the connection between gender roles within the family and fertility. It explains women's activities outside of the home in two stages. In the first stage, in line with what neoclassical and second demographic transition perspectives posited, with a dramatic rise in labour force participation, women's responsibilities in paid work increased, yet their labour in unpaid work stayed the same. Efforts in the labour market, coupled with domestic tasks created a double burden or what Hochschild and Machung (1989) termed a "second shift" for women. Since having children increased both the total work time and the number of activities in the household, exacerbating the double burden women have, women responded to this role strain reducing their fertility (Espenshade, 1972; Lesthaeghe, 2010). As most theorists argue while this first stage of the gender revolution, no doubt paves the way for women's emancipation, it is replete with family stress and fertility decline (e.g., Espenshade, 1972; Goldscheider et al., 2015; Lesthaeghe, 2010).

In the second stage of the gender revolution, women's labour force participation and gender equality both in the public and the domestic spheres became widespread. While the first stage of the revolution was marked by women's increasing participation in work, the second stage was marked by men's increasing participation in domestic labour. With established gendered norms being continuously challenged and with men's increasing participation in the domestic sphere as systematic and routine role sharing, women's motivation to continue childbearing and realize their desired number of children increased (Goldscheider et al., 2015). Thus, this second stage has been characterized by higher fertility, as well as high-quality relationships between the partners and decreasing rates of divorce.

Extensive literature provides evidence that when there is equality in the family where husbands share both domestic labour and childcare, relieving women from the double burden, partners' relationships become more fulfilled and they have an increased desire to continue childbearing (Brinton et al., 2018; Cavalli \& Rosina, 2011; Duvander \& Andersson, 2006; Freeman et al., 2018; Kan \& Hertog, 2017; Mills et al., 2008; Neyer, Lappegard, \& Vignoli, 2013).

However, it is important to note that this association is not always straightforward, with a sizeable number of studies reporting mixed or conflicting findings. The variations in the findings stem from differences in the definition and measurement of gender equality and fertility as well as peculiarities of social context. For example, numerous studies in the demographic tradition, including this study, refer to gender inequality as a more accurate concept to describe power relations in a household (Mason, 1986). Mason defines gender inequality at the family level as "a gender system's socially constructed expectations that prescribe a division of labour and responsibilities between women and men and grant different rights and obligations to them" (Mason, 1997, p. 158). In terms of measurement, while some studies measure equality in the family using weekly hours of housework (e.g., Brodmann, Esping-Andersen, \& Guell, 2007), others draw on respondents' self-reports of housework participation, scoring the frequency with which they undertook some specific household chores, including cleaning and meal preparation (e.g., Kan \& Hertog, 2017). Others focus on respondents' perceived satisfaction with the sharing of home-based tasks (e.g., Tazi-Preve, Bichlbauer, \& Goujon, 2004). Also, some studies focus on couple context (e.g., Singley \& Hynes, 2005). 
In regard to fertility, studies use different ways to operationalize the fertility outcome. While most research focuses on continued childbearing for different parities (e.g., Aassve et al., 2015; Cooke, 2009; Goldscheider, Bernhardt, \& Branden, 2013; Miettinen et al., 2015; Torr \& Short, 2004), abundant research examines fertility intentions (e.g., Brinton et al., 2018; Cavalli \& Rosina, 2011; Freeman et al., 2018; Harknett, Billari, \& Medalia, 2014; Kan \& Hertog, 2017; Mills et al., 2008; Neyer et al., 2013; Yang, 2017; Yoon, 2017).

Studying fertility intention occupies a significant place in fertility research since it is an important component and determinant of fertility behavior (Philipov, Thévenon, Klobas, Bernardi, \& Liefbroer, 2009). As Miller (2011, p. 76) describes, fertility intention is part of the motivational antecedents of the fertility-related behaviors of individuals. These antecedents follow "a sequential process" which begins with non-conscious motivational dispositions (traits) for having children, that then leads to conscious desires and intentions to have children or not, and finally to childbearing behavior or its avoidance. ${ }^{1}$ Most of the research on gender-fertility relationships focuses on fertility intentions rather than individuals' desired/ideal family size, since exploring fertility intentions reveals more realistic outcomes than fertility ideals (see Freeman et al., 2018).

Another related factor that affects fertility intention is social context. Miller, Severy, and Pasta (2004) stress that fertility intentions are influenced not only by the perception of each member of a couple but also by the perception of the desires of other family members. For this reason, as Miller et al. (2004) argue, the very nature of social context should be taken into account when explaining the formation of fertility intentions since "in less individualistic, non-Western cultures a pattern of decision-making involves the extended family" (p. 204). Moreover, in regard to the gender dimension, the regional and cultural norms as well as public policy influence the pace of transition to the gender revolution (Goldscheider et al., 2015). Cross-national research provides evidence that contextual factors including gendered norms and public policy determine both family roles and fertility decision-making. For example, in a qualitative study using data from two countries with very low fertility (Japan and Spain) and two countries with slightly higher fertility (the USA and Sweden), Brinton et al. (2018) investigated how gender inequality may generate a gap between women's fertility ideals and intentions in each of these countries. They found that while American and Swedish female interviewees are more likely than those in Japan and Spain to mention unequal family roles as a reason for their fertility ideals and intentions gap, gender inequality was more significantly associated with low-fertility intentions among highly educated interviewees in Japan and Spain.

In a social context with fertility reversal (e.g., Nordic countries), studies in general find a positive link between men's increasing involvement in the domestic sphere and both the probability and intention of having a second child (Brinton et al., 2018; Goldscheider et al., 2013; Miettinen et al., 2015; Oláh, 2003), despite the fact that in these social settings state provisions might mitigate the need for family support, thereby making men's contribution to childcare or housework less relevant for continued childbearing (Goldscheider et al., 2013). It would be

${ }^{1}$ Warren B. Miller describes the motivational antecedents to childbearing using a Traits-Desires-Intentions Behaviour (T-D-I-B) theoretical framework, which is a useful perspective in fertility research. For more information on this theoretical framework see his works: e.g., Miller 1994; Miller and Pasta 1993, 1994, 1996. 
interesting to compare these results against other low-fertility and low genderequal societies. Research shows that in many European countries with lowfertility trends, men's increasing contribution to domestic work does affect fertility intentions. For example, while Oláh (2003) documents a positive influence of a more equal sharing of housework and childcare on intentions to have a second child in Hungary, Mills et al. (2008) show a negative association between an unequal division of housework and mothers' intention to have a second child in Italy. Again in countries where the male breadwinner family model prevails, an unequal domestic sharing suppresses fertility intentions (Brinton et al., 2018; Freeman et al., 2018). As Goldscheider et al. (2013) suggest in these less egalitarian contexts where institutional support is not available, families supporting women trying to strike a balance between work and family tasks would be more necessary than for example, in Scandinavian countries.

Importantly, most research examining the domestic gender equality and fertility link primarily examine this subject in the Western setting, and there is an emerging literature exploring this relationship in non-Western settings, most of which focus on lowfertility countries in East Asia (Brinton et al., 2018; Freeman et al., 2018; Kan \& Hertog, 2017; Kim, 2017; Yang, 2017; Yoon, 2017). It would be useful to explore this link in a different social context which is neither Western European nor North American or East Asian with very different gender norms and fertility patterns. As such, studying a Middle Eastern context is crucial to better investigate to what extent the gender revolution framework is relevant to gender-fertility relationships in a non-Western setting.

Studying Turkey in this respect is important, since to our knowledge, no single study examined gender-fertility relationships in Turkey. With its peculiar gender relationship and dramatic decline in fertility for the past four decades, which is currently slightly below the replacement level with the western parts of the country already experiencing below replacement fertility, Turkey provides an interesting location to examine this relationship. As I discuss in the following section, the persistent fertility decline for the last four decades has created considerable concern among the political elites and the public that Turkish fertility is moving toward even lower levels. For example, a recent survey reports that Turkish people expect fertility to decline and small families to increase in the next 20 years (Kavas \& Thornton, 2019). The wide concerns of fertility decline urge the current government to expend considerable efforts on encouraging higher fertility.

It is in this context that this paper examines how equality in domestic labour and childcare is connected to intention for continued childbearing for Turkish women, and the extent to which the gender revolution framework is relevant to gender-fertility relationships in Turkey. Although I focus on a single country, the study findings have the potential to generate comparative data for better insight into the domestic equalityfertility relationship and advance the research in this area. Also, given the lack of research in this region, this paper is exploratory in nature.

This study uses qualitative data and it draws on women's perceptions and experiences in one setting to identify mechanisms that may link women's perception of equality in home-based tasks to their fertility intention. The strength of using a qualitative approach when studying fertility intention stems from the fact that qualitative analyses are better at "revealing the variability and complexity of 
decision-making" (Philipov et al., 2009, p. 10). Explaining formation of fertility intention calls for a more nuanced understanding, because as Miller et al. (2004) describe, even though childbearing is a dyadic reproductive behavior, fertility intention comes into being separately within each member of the reproductive dyad with the interplay of various forces contributing to its formation. Moreover, individuals' perception of their partners' reproductive desire, as well as perceived norms, attitudes, and values are important in the process of fertility decisionmaking. Also crucial in this process is individuals' subjective perception of "reality" constraints and priorities shaping their fertility intention (Miller et al., 2004: 194). Therefore, eliciting respondents' subjective perception and their own narratives of formation of fertility intentions are important for a more nuanced and comprehensive understanding, which is accomplished through qualitative analysis.

\section{Sharing of domestic work and the link to fertility in Turkey}

While there is ample research reporting changes in Turkish fertility from the 1950s onwards, there is very limited attention to the gender dimension as a potent driver causing changes in fertility trends. Historically, the Turkish Republic has witnessed an accelerating downward trend in the total fertility rate from a high of 7.1 children per woman in 1930, to 4.3 in 1978, to 3.1 during the late 1980s, and finally reaching 2.07 in 2017 (Turkish Statistical Institute (Turkstat), 2018). More recently, as a large-scale survey shows, there have been very large increases in contraceptive use with $92 \%$ of ever-married women having used a contraceptive method at some time during their reproductive years (Turkish Demographic and Health Survey (TDHS), 2013).

Turkey's total fertility rate is slightly below the replacement level, in many ways, this rate could be considered high fertility when compared to other lowest-low-fertility countries. However, regional differences in fertility trends across the country paint a different picture. According to the most recent Turkish Demographic and Health Survey (TDHS) (2013), both the western and central regions of the country, which have larger population size and are richer in terms of manufacturing and services, are already experiencing below replacement fertility, with total fertility rates ranging from 1.89 to 1.93 births in the central and western regions respectively.

Also, as the Demographic and Health Surveys indicate, there has been persistent fertility decline since the 1980s, creating concern among policymakers that fertility will decline further. The concern that fertility may continue to decline challenges the country's antinatalist population policy, with the present government now promoting higher fertility and encouraging couples to have multiple children through adopting policy measures such as extended maternity leave and child allowances (Kavas \& Thornton, 2019).

The reasons for declining fertility are usually attributed to overall socioeconomic changes the country has faced for the last six decades and to the increasing status of women, especially improved education. D'Addato, Vignoli, and Yavuz (2007) investigated the potential reasons that drove the decline of higher order births in the Southern and Eastern Mediterranean context in three representative countries: Egypt, Morocco, and Turkey. They found socioeconomic changes including increasing urbanization, rising literacy, and diffusion of modern values as mechanisms that shaped people's reproductive behavior. These authors also found that in Turkey, women with urban 
backgrounds and higher education move more rapidly toward smaller family size than women with rural backgrounds and lower education. When compared to Egypt and Morocco, Turkish fertility decline manifests patterns that are "similar to a typical lowfertility pattern of a developed setting" (p. 12). Another study documented fertility decline with a regional perspective and found important discrepancies in reproductive behavior across different groups of women (Yavuz, 2006). Using the Demographic and Health Survey data Koç, Türkyllmaz, and Adalı (2013) addressed age at first birth and its implication for declining fertility and documented evidence of a trend towards the delayed onset of childbearing in Turkey.

With respect to the gender dimension, one strand of research explores women's status and fertility relationships focusing particularly on women's decreasing labour force participation. This literature emphasizes the role of cultural factors and the deep-seated norm of the gendered division of labour which plays a strong role in preventing women from greater participation in the workforce (Dayioglu, 2000; Gündüz-Hosgör \& Smits, 2008; Özbilgin \& Healy, 2004; UysalKolaşin, Paker-Uncu, Cansuz, \& Kökkızıl, 2015). It has become near-universal that Turkish women retreat from the workforce after they get married and have children (see Akadlı-Ergöçmen, 1997; Uysal-Kolaşin et al., 2015). Childcare is primarily carried out by mothers with the most recent nationwide Family Structure Survey reporting that $86 \%$ of mothers are the main childcare provider forgoing any institutional or extended family childcare support (Turkish Statistical Institute (Turkstat), 2016). Another recent survey reports that "women's strong identification with motherhood is an overarching dynamic and a stronger predictor of women's lack of interest in joining the workforce" (Uysal-Kolaşin et al., 2015, p. 3).

The normative division of labour is a deep-seated convention in the country and families are characterized by inegalitarian gender relationships (Fikret-Pasa, Kabasakal, \& Bodur, 2001). In fact before its reform in 2003, the gendered division of labour was legally supported by the civil code which prescribed men as breadwinners, the head of the family, and women as homemakers (Illkkaracan, 2012). However, studies reveal that recently there are changes in gender relationships. For example, gender roles are expanding, especially in the urban, middle-class, and professional population of Turkey (e.g., Aycan, 2004). Aycan (2004) reports that while women are more active in professional work life, men are also more active in family life. In addition, the division of housework within a family is facing challenges, according to a study Turkish women cited spousal support as the most important factor in reducing work-family conflict after they become mothers (Aycan \& Eskin, 2005). In a similar vein, the Turkish Demographic and Health Survey (TDHS) (2013) data reports similar findings, where $75 \%$ of women stated that couples should share housework equally.

In sum, the entrenched norms about a couple's domestic role are changing with potential effects on fertility decision-making; however, as is evident from the review of the literature, there is very limited research on these trends. In the Turkish setting, to the author's knowledge, there is no single study on the gendered division of labour and its link to fertility. Therefore, this study aims to shed light on this relationship between the division of labour and fertility in this Middle Eastern region. 


\section{Data collection, interview guide, participants, and analysis}

Data for this study was collected between June 2015 and January 2016. The author of this study and the two research assistants, skilled in qualitative interviewing, conducted 51 in-depth, face-to-face, semi-structured interviews with women in several cities of Turkey. Using a snowball sampling technique, participants were initially recruited from a daycare center in downtown Istanbul. These participants were then asked to identify other eligible women living in their communities with at least one child. During this recruiting process, seven cities in various regions of Turkey were visited. Before the interview, the women were informed about the process and the option to withdraw at any time. All the women scheduled for an interview participated with no exception. The time and location of the interview were determined according to each respondent's request. Interviews lasted for about an hour. All interviews were conducted in the respondents' mother tongue (Turkish) and voice recorded.

The majority of interviews were conducted in the respondents' homes. After the interviews, the two research assistants transcribed the interviews verbatim and the author of this study translated them into English.

\section{Interview guide}

This current study is part of a larger research project which was specifically designed to investigate the influence of social networks on fertility decision-making. While the aim of this research project was specific, the semi-structured interview guide included diverse questions allowing the author to study various other aspects of Turkish women's fertility decision-making. We began our interviews by asking a series of demographic questions and continued with questions about issues related to marriage, the transition to parenthood and higher order births, fertility control, and childcare arrangements. We focused on respondents' accounts of childbearing and childrearing experiences, which also included a set of questions about respondents' fertility decision-making process, their fertility ideals and intentions, the meaning of having children, and their attitude to ideal parenthood. We also had specific questions about participants' current work experiences (past work experiences for quitting women) and work conditions (e.g., working hours, commuting) and daily routines, their attitudes to work-family conflict, the actual division of labour in their household, and their knowledge and attitudes to the gendered division of labour in general. This current work mainly draws on the following questions about fertility intentions and the gendered division of housework. Regarding fertility intentions, we asked: "What is the ideal number of children that you would like to have?", "let's imagine five years from now, do you think you will have one (more) child?", "If not, Why?", "How would you feel if you did not have the ideal number of children that you would like to have?", "Would you, for example, feel regret?"

With respect to the gendered division of labour we asked; "Who usually does the housework in your household?", "To what extent does your husband help you with housework and childcare?", "How do you feel about your husband's involvement (or lack of involvement) with the housework and childcare?", "Should both men and women equally share the housework and childcare", "Who do you think should be the main caregiver?", "Should both men and women work to contribute to the family 
budget?", "Should women with preschool children work?". In addition to these questions, we encouraged participants to elaborate on who does what/when and their feelings about it.

It is the strength of the qualitative approach that it enabled us to acquire women's self-reports of the reasoning they offered for their reproductive behaviors. The openended questions and use of prompts during the interviews induced respondents to talk openly and discuss the issues we posed allowing us to further explore their subjective perceptions and dilemmas as well as meaning. For example, in order to capture respondents' own thoughts about the constraints underlying their fertility intentions more broadly, we asked about women's ideal family size, fertility intention within 5 years, and whether or not they would feel regret if they did not realize their fertility aspiration; eliciting this information would have been difficult to acquire with a survey questionnaire (Brinton et al., 2018).

Moreover, regarding the gendered division of labour using the in-depth interview method allowed us to encourage respondents to provide details, which yielded a more complete description of the division of housework and childcare, as well as information about their subjective perceptions about the circumstances leading to a particular division and their feelings about it (see Matthews, 2005).

\section{Participants}

The women providing data for this study differed widely in educational level, ranging from basic schooling to postgraduate degrees as well as in age ranges and the region of residence. Although I did not attempt to select on these characteristics, the interviews revealed diverse demographic characteristics. No doubt, the considerable heterogeneity within this sample has its implications on these women's gender ideology and fertility intention. I discuss some of these implications in my findings. In terms of employment status, the sample of this study was restricted to women who were employed full time or quit work for definite or indefinite period of time. I excluded women who had never worked since the division of housework is more of an issue among dual-earner couples who tend to consider household labour as an extension of paid labour and which is not at all "trivial" (Presser, 1994). Thus, I expected that sharing domestic duties had a stronger effect on childbearing among women who in one way or another were involved in the labour market. In addition, I excluded some of the respondents who were not interested in the topic and did not provide information for my analysis, which was the case for five women. Little discussion took place among these respondents about the gendered division of labour, and these women said virtually nothing about the potential link between the availability of housework support and fertility decision-making, despite questions and probes during the interviews.

Altogether, 32 women comprised the sample for this study and all names of respondents that appear below are pseudonyms. The sampled women were aged 24-43 years and all were born in Turkey. In terms of the number of children, these mothers varied greatly; while 17 women had a single child, 12 women had two children, and three women had three children. 


\section{Analysis}

The transcriptions were read, and thematic analysis and coding of the transcripts were performed by the author (Strauss \& Corbin, 2015). Open codes were formed by summarizing the quotations and particular statements as "in vivo" codes. After careful scrutiny, the codes most relevant for the study purpose were chosen and they were sorted into the conceptual divisions and subdivisions in accordance with their content and meaning. Finally, employing an inductive approach for the analysis of qualitative data, I analyzed the coded quotations to generate a conceptual framework; the theoretical framework of gender revolution emerged during the analyses of the data.

\section{Findings}

My findings showed that the traditional gender split in family roles had differential effects on women's fertility decision-making. The data exhibited that gender sharing in the household tasks and childcare are not equal and the weight rests mainly on women's shoulders, except for a minority; this was the case for all the women participating in this study. As their fertility preferences manifest, respondents reacted to this gender system shaping their reproductive behavior in distinct ways. It is important to note that the structure of the interview allowed women to elaborate on other factors that may affect their reproductive decisions; it enabled them to voice their experiences and concerns when discussing circumstances and constraints shaping their fertility intentions. One commonly cited explanation was financial issues where almost all participants voiced concern about the cost of childbearing, a recurrent finding observed in most demographic studies focusing on fertility decision-making (e.g., Brinton et al., 2018; Freeman et al., 2018; Schoen, Young, Constance, Fields, \& Astone, 1997). While other topics were discussed in the interview too, the reasons that led me to focus on the gendered division of labour in the analyses stemmed from the fact that it is an under-investigated topic in Turkey. Also, as the participants' narratives indicated, the topic appeared highly relevant for 32 women in this sample. In the light of respondents' different gender role attitudes and fertility choices, the study sample was divided into three groups to review analytic findings. A total of 32 women out of the original sample $(n=51)$ fit into these analytical categories.

The first group, named the "Double-burdened women" ( $n=15)$, had a commitment to gender egalitarian ideology and were strongly critical about the unequal division of household tasks and the way that social norms undergirds this normative state. Even though they expect both sexes to share housework equally, the women in this group failed to have that ideal state in their household. For the most part, they were primarily bearing the burden of housework and childcare and rarely received help from their husbands. As the data showed, experiencing first-hand the increase in involvement in housework after the birth of the child, these women were either clearly reluctant or hesitant to continue childbearing.

The second group, the "Traditional providers" $(n=9)$, on the other hand, were less expressive about the way household tasks are disproportionately shared between spouses. Just as they did not strongly criticize unequal family roles, they did not sharply change their fertility plans. Spousal help was unavailable; therefore, these women devised several strategies including outsourcing to reduce the amount of routine housework. 
The final group was the "Equal sharers" $(n=8)$. The women who fell in this group told us about a symmetrical sharing of housework in their household. As the quotations reveal, these women were somewhat positive about continuing childbearing and in some cases, their intention for further childbearing was explicitly related to the equal gender split in family roles that they described during the interviews. Overall, the study women's narratives indicated an association between husbands' involvement/lack of involvement in housework and wives' desire for more/fewer children in the Turkish setting. Moreover, they provide a perspective in regard to the stage of gender revolution Turkey currently represents as well as the future prospect of equal gender roles. In what follows, I discuss each group and present representative quotes.

\section{The first group: the double-burdened women}

The 15 interviewed women comprising the Double-burdened women's category were all women who had at some point participated in the labour force and as they reported they were undertaking a greater part of household tasks and childcare than their husbands. This prevalent gender split in family roles forced many of these women to leave the labour force in order to shoulder the lion's share of housework and childcare. As the quotations unravel, the women interviewed responded to the pressures of second shift either through reducing their fertility or through withdrawing from work completely. This pattern seems to be parallel to the trends described by neoclassical economic theory or first stage of the gender revolution theory whose proponents explain the decline in fertility with women's rising labour force participation and struggle with "the second shift" (Becker, 1985; Goldscheider et al., 2015).

These interviewed women talked extensively about the gender-asymmetric division of housework and childcare. They were aware that their involvement in the labour force breaches the traditional gender split; however, when it comes to the division of labour in the household, family roles continue to be a traditional kind with women shouldering a greater share of housework and childcare. The following descriptions from women's narratives show their husbands' lack of involvement in household labour:

It's generally me, I do all the stuff, he does things once in a while, if he feels like it. (Feyza)

Well, I get up early, set the breakfast and prepare the kids for school, all he does in the meantime is just saying "kids come on you are gonna be late" (İpek)

My husband? No, he never helps, not even once in a while, sometimes he fixes things around the house but about cleaning, cooking and other stuff no, never! (İldem)

No, he doesn't help, I mean never! He doesn't feel like it, he doesn't need to do anything. (Keriman)

No, unfortunately, no, they (men in general) don't really help, you know, you can never rely on their help. (Melike)

I found that for the majority of these women, a sporadic sharing of housework or unspecified help on an as-needed basis is not their main desire, what they want is 
systematic and symmetric work sharing, as they reiterated in Turkish during the interviews, iş bölümü (the division of labour). These interviewed women, particularly the higher educated ones (e.g., with university/postgraduate degrees), were cognizant about gender ideals in family roles and were more knowledgeable about gender issues. They were critical of the fact that it has been the normative gender system that undergirds this trend to the disadvantage of women. Keriman, the only part-time-employed respondent and university graduate criticized her husband's lack of involvement, putting the blame on her husband's parents for raising their child with a traditional gender split. "A wife is a homemaker and a husband is a breadwinner" was her husband's justification for why he removed himself from the domestic sphere. To his mind, a woman's working has been a kind of violation of the cultural norms of the division of labour in family and a spouse's domestic sharing would be nothing but the reinforcing of this violation. According to Keriman, his upbringing with this mindset was still shaping her husband's housework behavior. Moreover, while her part-time employment was breaching the normative gender system, it was giving her sufficient time to shoulder "the second shift" and compensate for her failure to conform to socially accepted standards. Another respondent, Nil, a teacher-cum-graduate student reflected extensively on gender inequality in the household. Throughout our interview, Nil talked about how the gendered division of labour is just one representation of the broader unequal gender system and that most women are complicit in this outcome since "they raised their children according to the gender norms".

\section{Women's reactions to the second shift}

I found that the women who fell into the "Double-burdened women's category were confronted with their partners" strong resistance to the equal division labour at home. They resented the idea of asking for help from their partner and wanted help to be inherent to their relationship. When they fail to achieve domestic sharing, they devised work-family strategies with women making the most changes either in their employment status or in fertility preferences or, in some cases, both.

As is shown in Table 1, these women made different work arrangements with many quitting work temporarily, while some of them withdrew from the labour force permanently to devote all their time to family commitments. Nil told me how she was tired of pushing her husband to help with housework every single day. Her position of being the primary caregiver in all conditions placed an additional strain on their family relationship and led her to quit work. Despite her teaching aspiration and strong criticism of gender inequality, she felt that it fell on her to find a way to strike a balance between family and work.

With respect to the strategy of limiting their fertility preferences, the women's accounts show that for the vast majority of the women included in the "Double-burdened women" category, the link between domestic sharing and fertility preference is crystal clear. Irrespective of their employment status, these women prevalently carried out both domestic and caregiver tasks. As a way to reduce the amount of work and the related strains of the second shift, they lessened their desire to have additional children. When queried about their future fertility plans, almost all of these women told me that they did not intend on having one more child. In many of the cases, the unwillingness 
Table 1 Respondents' demographic characteristics, ideal fertility, and fertility intention

\begin{tabular}{|c|c|c|c|c|c|c|}
\hline & $\begin{array}{l}\text { Age } \\
\text { group }\end{array}$ & Education & $\begin{array}{l}\text { Employment } \\
\text { status }\end{array}$ & $\begin{array}{l}\text { Current } \\
\text { fertility }\end{array}$ & $\begin{array}{l}\text { Ideal } \\
\text { fertility }\end{array}$ & Fertility intention? \\
\hline İpek & $35-40$ & University & Working full time & 2 & 3 & No \\
\hline Cansu & $30-35$ & University & Working full time & 1 & 2 & No \\
\hline Figen & $40-45$ & Middle school & Working full time & 3 & 4 & No \\
\hline Feyza & $30-35$ & High school & Working full time & 1 & 3 & Yes, two more children \\
\hline Gonca & $30-35$ & Middle school & Quit & 2 & 3 & No \\
\hline Irem & $35-40$ & $\begin{array}{l}\text { Primary } \\
\text { school }\end{array}$ & Working full time & 3 & 3 & No \\
\hline Keriman & $30-35$ & University & Working part-time & 2 & 3 & No \\
\hline Kezban & $40-45$ & University & Working full time & 2 & 3 & No \\
\hline Melike & $30-35$ & High school & Quit & 1 & 1 & No \\
\hline Melis & $25-30$ & High school & Quit & 3 & 4 & No \\
\hline $\mathrm{Nil}$ & $25-30$ & MA & Quit & 1 & 3 & Yes, one more child \\
\hline Sevgi & $25-30$ & Middle school & Working full time & 2 & 4 & No \\
\hline Selda & $25-30$ & University & Quit & 2 & 2 & No \\
\hline Tülay & $30-35$ & High school & Quit & 2 & 4 & No \\
\hline Ayşe & $30-35$ & High school & Quit & 2 & 3 & No \\
\hline
\end{tabular}

to have one more child was expressed with strong words. For instance, Melike reacted very emotionally, virtually bursting out "No" when she was asked about her intention to have another child. Other women were also very clear on their position, Ayşe told that she would "never" consider having a child and Cansu said, "she will not have a child under these conditions" (referring to her husband's lack of participation in housework and childcare). As I stated previously, in many ways, limiting their fertility was these women's response to the disproportionate share of housework and childcare they carry out. For example, one respondent, Cansu, who is a dual-burdened mother with a single child expressed clearly that her unwillingness for a second child is related to her husband's disproportionate share of housework. For Melis, even the idea of having another child was daunting. Having three children born one after another and caring for them all alone without any support from her husband was both physically and psychologically demanding for her. In addition, since she had to quit a fulfilling job, she is now waiting for a day when she returns to her "life" which she has postponed for an indefinite period of time. Having another child at this point meant not only going through all those difficulties "all alone" again, but it would also be a roadblock on her way to reach her aspiration to return to work. Keriman's case provides an even more interesting story. She resists her husband's desire to have a large family through having a third child, she says "it is easy for my husband to ask for three, four, even five children since it would be me who would take care of all tasks of childrearing even after the kids start school”. Keriman explains her reasoning for not positively responding to her husband who is fond of having many children around yet not an active participant in any of the home-based tasks thus: "the important matter is caring for them, otherwise everyone loves children, they are really adorable."

Moreover, in some cases, mothers get hesitant and restructure their reproductive plans according to their husband's housework and caring behavior expecting a change with a helping hand; the following quotation is representative of this sentiment: "Well, 
I am discussing having a third child with friends and the biggest concern is my husband. I am just observing him (his housework behaviour) and thinking that it is too difficult to face all those difficulties by myself, you can think of having a third only when you have a husband who would share the burden. People say, it is fun to have a large family and stuff but that does not make sense, that's not relevant, because you bear the brunt you know" (İpek).

Another respondent, Feyza, a full-time working mother of a single child, told me that she can think of progressing to a second child only under such ideal conditions where either her husband increases his share of housework and caring duties or she will leave her job for good. When I asked which of these options seems more possible at this point she says she might need to quit work in case of a second pregnancy.

It is important to note that although I argue through the respondents' quotations that the traditional division of labour was an important motivation for these women's fertility decision-making, this does not mean that I underestimate other possible factors that might play a role in women's fertility plans. For example, I consider respondents age as a potential dynamic in their fertility decision-making since it refers both to the biological capacity of childbearing and completed family size (Philipov et al., 2009). Table 1 displays the sample which includes diversity with respect to the age where most of the respondents are either in their late thirties or early forties. The concentration of older-aged women in the Double-burdened women's category, with most of them having lower fertility intentions lead me to think that biological constraints might also explain these women's lower fertility intention. Additionally, women's current fertility might be determinant of their fertility intention. As I just discussed most of these women have higher fertility with two-thirds of women having two or three children already. Despite their higher fertility ideals, it might be that these women considered that they reached the average completed family size of two births, conforming to the two-child norm prevalent in the country for the last three decades (Ataca et al., 2005; D'Addato et al., 2007).

\section{The second group: the traditional providers}

The nine women who fell into the "Traditional providers" category exemplify the argument reiterated in feminist research that gender stratification throughout society sustains norms that reinforce men's and women's acceptance of the traditional allocation of household work (Chafetz, 1988; Presser, 1994). As the data show, these interviewed women seem to be intensively socialized into such Turkish norms that prescribe women to be "sacrificial mothers" and "the gatekeeper of the family" and men the breadwinner. What I particularly found in these women's accounts is that they did not express strong ideological commitment to gender equality in a family and their support for an equal division of housework in their household was less evident. It might be the reason why these respondents generally talked about just spousal help and did not use the word iş bölümü (the division of housework). Particularly, the women who quit work after childbirth consider the unequal share of housework just normal and accept the fact that with their unemployment they can shoulder more responsibility in the household. For example, I heard the following statements from two respondents: 
" ... because I am the one who is at home, I take care of all the housework and care." (Ezgi)

"I do the housework stuff now that I am home and he does outdoor things: gardening, fixing things." (İmran)

The women's narratives unravel the fact that housework reinforces the deeply ingrained stereotypes that paint men as breadwinners and women as the primary homemaker and caregivers. When these husbands tend to increase their housework share, it is usually very little and only in "situational exigencies" such as when the women are sick, need to work a double shift, or have a difficult pregnancy (e.g., morning sickness), etc. The data shows that these women are generally pleased with any slight increment in the housework share provided by their husband, for example, Yasemin, a full-time employee, mother of a single child, says: "He is really helpful in that respect, if I tell him that I am too tired he does things to help me. During my pregnancy in my fifth month, I couldn't cook you know for days, I was lying, for the most part, he cooked and vacuumed the house then."

More interestingly, for these women, spousal help to the point where it would run counter to social expectations would then come as a sacrifice for which they would be grateful. The following extract from one of the interviews evince this phenomenon:

R: Yeah definitely, my husband is my biggest support since our daughter was born.

He even did things that a father would never do.

Int: Really, like what for example?

R: Well, I was leaving the five-month-old baby to him and giving him a list of things to do like changing diaper, feeding and burping her. He was really doing them all (Handan, full time employed, mother of the single child).

\section{Having some help increases fertility}

When asked about their fertility plans, the interviewed women included in the "Traditional providers" category responded more positively compared to the women in the first category. Nevertheless, without having a consistent sharing of domestic work in their household, how these women will handle the care for another child remains an outstanding question.

As the data reveals, one important strategy the majority of the interviewed women resorted to was outsourcing some of the domestic tasks to a service provider or a domestic helper from the public, depending, by definition, on their economic power. Three women hired domestic helpers to reduce the domestic burden including household chores but excluding childcare tasks. Four women relied on informal help from the grandparents, primarily their own mothers. And one woman relied on her teenage daughter both for housework and childcare. As the previous research suggests, reducing domestic burden has a positive impact on women's fertility decision (Hazan \& Zoabi, 2014; Raz-Yurovich, 2016). In line with the previous research, the strategies these women devised to reduce housework through means other than equal domestic sharing had a positive influence on their intention to transition to second or higher order births. 
Nonetheless, it is important to state that while relying on outsourcing and informal help may increase these women's ability to relieve the burden of domestic labour, it, in effect, may have a negative influence on changing gender relations with respect to domestic sharing in a more egalitarian direction. As extensive research states, workfamily policies either at the institutional or individual level may ameliorate current difficulties, yet they may run counter to gender egalitarian behaviors in family and strengthen the traditional division of labour between mothers and fathers (see Brines, 1994; Singley \& Hynes, 2005). As the data exhibited, relying on formal or informal support inhibited reallocation of housework and caring tasks in an egalitarian way; two respondents provided an example for this phenomenon. Gizem talked about how her husband gave up doing at least some of the housework that he was occasionally doing right after her mother moved in with them to help out with childcare. More interestingly, another woman, Şeyda, told me that relying on help from others helped her husband more than herself; her narrative tellingly shows the causation: "We were living together with my parents-in-law back then. They were a great support to me ... As a matter of fact, this benefitted Zeki (her husband) more than it did me. He withdrew himself completely from the domestic sphere. He was only providing financially for his family and doing nothing other than that."

To sum up, while my analysis suggests that relieving the burden of domestic labour may increase these women's chances to consider having an additional child, I recognize that two other potential dynamics: women's current age and fertility may play a role in their decision-making as well. The women who intend to continue childbearing are relatively younger, having a longer reproductive period compared to the other four women who are in their late thirties, and expressed low-fertility intention. More importantly, as Table 2 displays, the women who intend to have an additional child have low fertility with all of them having just one child. Therefore, not yet completing their family size and having a longer fertility period ahead of them might play a positive role in these women's reproductive choices.

\section{Third group: the equal sharers}

In contrast to the women discussed above, the women included in the "Equal sharers" category described a systematic, consistent, and equally divided role sharing in their households. For example, one woman says that "they have a very clear and distinct

Table 2 Respondents' demographic characteristics, ideal fertility, and fertility intention

\begin{tabular}{|c|c|c|c|c|c|c|}
\hline & Age group & Education & Employment status & Current fertility & Ideal fertility & Fertility intention? \\
\hline Ela & $35-40$ & High school & Working full time & 1 & 2 & No \\
\hline Seher & $30-35$ & University & Working full time & 1 & 3 & Yes, two more children \\
\hline Serra & $35-40$ & University & Working full time & 2 & 2 & No \\
\hline Handan & $30-35$ & High school & Working full time & 1 & 2 & No \\
\hline İmran & $35-40$ & High school & Quit & 2 & 3 & No \\
\hline Ezgi & $25-30$ & High school & Quit & 1 & 2 & Yes, one more child \\
\hline Yasemin & $25-30$ & University & Working full time & 1 & 3 & Yes, two more children \\
\hline Gizem & $20-25$ & High school & Working full time & 1 & 2 & Yes, one more child \\
\hline Şeyda & $35-40$ & University & Working full time & 1 & 3 & Yes, one more child \\
\hline
\end{tabular}


division of labour (iş bölümü) in their household", she goes on describing this division of labour thus: "I cook, the kitchen as a whole is on me and he does the cleaning, including vacuuming, wiping and all other stuff; he does his own ironing himself; I don't prefer clothes that need ironing; Friday is my off day I am with the baby all day and when he is back from work he takes his turn and cares for her and stuff". (Sima)

These women expressed strong ideas about the necessity of having a more equal division of labour for a fulfilling marital relationship and having children and stated that especially for employed women, husbands' lack of participation in household labour was unacceptable. Betul, a young mother says: "He sees that I am doing my hardest to combine work and family, and he has to pitch in". Another woman Rezzan says; "If my husband didn't support me I would have divorced by now, seriously, I would have divorced in such a situation because it is too much (combining work and family load) and I wouldn't have born all the burden".

Some of these women explicitly referred to gender roles. For example, Tuğçe a full-time working mother of a single child stated that "she is not a woman who thinks women should take care of the house and men provide for the family", she firmly believes that housework should be equally shared as in their household. An interesting case comes from another full-time working mother of two, Mine. Even though Mine's husband does not have strong gender ideals like his wife has, and prefers not to participate in domestic labour, Mine expended significant effort to motivate her husband to participate in housework because she wanted to raise her two children with a gender egalitarian mindset and believes that in order to do that parents need to be the role models. She says: "Now my kids do not think it is only the mother who does all at home, they see that both the mother and father can share housework". A third respondent, Sima, points out that there has to be a fine line between the notions of equal division of labour versus husband's help. During the interview, Sima emphasized that when household labour is shared, it is usually pictured as if the couple is breaching the boundaries of the normative order and that the husband is doing a favor for his wife. To her, men and women sharing the workload should be the normative order, her own words tellingly illustrate this sentiment: "We have a very clearly divided and rigid work share in our household, but I wouldn't have accepted anything different from this. My husband is a fair person in that respect. I am not saying that he is understanding because if I say that he is understanding it means that he doesn't have to share but he is doing a favour for me, no! That is not how it is, to me, a man has to think that this is his job too, I am working every day as well."

As the above quotations show, these women referred to gender roles more explicitly than women in previously identified groups, and their narratives indicated that they were knowledgeable about gender issues and had positive attitudes to egalitarian role sets. It might be that their knowledge and attitude to gender issues are related to their higher education, which is also the case for some of the women in the first category. As Table 3 shows, the majority of the women in the "Equal sharers" category have university degrees and two women have postgraduate degrees. Their higher education and the way they discuss gender role concepts during the interviews indicate that higher education may play a role in shaping women's knowledge and attitudes to the gendered division of housework. 
Table 3 Respondents' demographic characteristics, ideal fertility, and fertility intention

\begin{tabular}{lllllll}
\hline & Age group & Education & Employment status & Current fertility & Ideal fertility & Fertility intention? \\
\hline Feryal & $25-30$ & University & Quit & 2 & 2 & No \\
Hediye & $30-35$ & University & Working full time & 1 & 2 & Yes, one more child \\
Mine & $25-30$ & High school & Quit & 2 & 3 & Yes, one more child \\
Tuğçe & $35-40$ & University & Working full time & 1 & 2 & No \\
Rezzan & $30-35$ & University & Working full time & 1 & 2 & Yes, one more child \\
Sima & $30-35$ & PhD & Working full time & 1 & 3 & Yes, two more children \\
Berrin & $25-30$ & MA & Working full time & 1 & 3 & Yes, two more children \\
Buse & $25-30$ & University & Working full time & 1 & 3 & Yes, one more child \\
\hline
\end{tabular}

\section{Intention for one more child}

The women's narrative indicated a connection between domestic equality and propensity to continue childbearing. It is important to note that there might be other mechanisms, e.g., women's relatively younger age and current low fertility, which might be playing a role in their reproductive choices. Because it is difficult to disentangle the mechanisms influencing their fertility decision-making, it is important to refer to respondents' own words to grasp the real line of reasonings they express. The women in the "Equal sharers" category clearly had a greater desire to have an additional child and at a minimum four respondents explicitly told me that their intention to continue childbearing is related to their husbands' equal participation in domestic labour and childcare, which indicates that gender equality in the domestic sphere may be more important in generating higher fertility intentions among this highly educated group. For example, Rezzan told me that her childbearing is dependent on a very simple formula of equal work at home with equal amounts of childbearing, which played important role in her decision to have her first child. Her husband's promise that he would adhere to this formula was reassuring for Rezzan to consider transitioning to parenthood, since "it was when she seriously intended to have a child." In another case, Feryal a mother of two explained how her husband's sharing of the housework and childcare encouraged her to have two children; the following extract clearly summarizes her story:

Feryal: My husband helped me in every aspect, he cooked, cleaned the house, did the shopping and even the laundry, he did all types of housework, and cared for Burak (her son). He really became an ideal husband.

Int: So, his being very supportive, did that encourage you to have your second child?

Feryal: Yes, it did. When he said "now that Burak turned 6 we could consider having a second child", I didn't hesitate. And we had our second son soon.

In sum, these women's attitudes to the gendered division of labour in the family and their intention for more children indicate that greater equality in sharing housework and childcare have a positive effect on their decision to progress to second or higher order births. Though fewer in number, the women included in the "Equal sharers" group tend to set a trend where egalitarian households provide a positive environment 
both for a fulfilling marital union and realization of fertility aspirations. In many ways, the narratives these women provide seem to lend support to the gender revolution framework which relates higher fertility rates to greater gender equality in the family.

\section{Discussion}

In this study drawing on qualitative data, I investigated whether there is a connection between the division of household labour, including childcare, and women's fertility intention in one Middle Eastern country, Turkey. Particularly, I asked whether husbands sharing of housework and caring tasks influence women's inclination to have an additional child in Turkey, a country characterized by low fertility and high level of gender inequality in both the institutional and familial level (Akadlı-Ergöçmen, 1997; Fikret-Pasa et al., 2001; İlkkaracan, 2012; Yavuz, 2006).

My qualitative analysis highlights a link between the amount and division of housework and childcare and fertility preferences among the mothers in this study. Consistent with previous research, my findings suggest that an unequal sharing of domestic labour and childcare which generally means an increasing workload for women is likely to depress women's fertility aspirations, whereas the equal division of labour within a home does indeed influence childbearing plans positively (see Brinton et al., 2018; Cavalli \& Rosina, 2011; Duvander \& Andersson, 2006; Freeman et al., 2018; Kan \& Hertog, 2017; Mills et al., 2008). The findings of this study show that there are variations between the categories of these women in regard to women's perception of the domestic division of labour and the extent it influences their fertility decision-making. For example, women in the first category, the "Double-burdened women," had a clear ideological commitment to domestic gender equality in principle, yet in practice, they did a disproportionate share of housework and childcare in their households. One commonality in these women's narratives was the reiteration of the feelings of unfairness from the burden they shoulder. These women responded to the pressures of the "dual burden" through withdrawing from work and reducing their fertility. The second group, the "Traditional providers," on the other hand, comprised women who more easily reconciled themselves with traditional Turkish norms associated with genderappropriate behaviors. While these women were quite attentive to discussions about gender roles during the interviews, they did not express strong ideas regarding gender equality in the family nor were they critical of the housework division of labour. "The situational bind" (Presser, 1994) forced these women to make practical arrangements to relieve the burden of housework and childcare. For example, many of these women outsourced housework or relied on informal help. Most importantly, compared to the first group, these women had a somewhat higher propensity to continue childbearing; apparently, an unequal distribution of housework did not discourage childbearing among these women. In many ways, the behaviour of these women illustrates "pre-gender revolution model", where they were still proceeding through the first half gender revolution (see Cherlin, 2016).

The final group, the "Equal sharers," represents women who evidently have egalitarian gender ideology and were able to establish much more systematic and equal sharing in their households. For these women, gender ideals were central to their marital satisfaction and fertility decision-making; some women expressed a causal link between equal sharing and their propensity to have an additional child. I should also note that 
the finding of this study was not consistent for all women in the study sample, since as I previously noted, there was a group of women $(n=5)$ who were excluded for their lack of interest in the discussion about the nexus between gender issues and fertility, providing little commentary on the subject. With their apathy to the discussion, these women were different from the women in the second category who were less expressive about the link between housework share and fertility decision-making than the respondents in two other categories, yet were more interested in giving their opinion and were more involved in the overall discussion than the five respondents who were excluded from the study sample.

It is important to acknowledge the difficulty of disentangling various forces influencing the complex process of reproductive decision-making. Therefore, in addition to the division of housework, I also consider other factors that might impact these women's fertility intention. As documented in Tables 1, 2, and 3, the study sample displays a considerable heterogeneity with respect to the region of residence, employment status, number of children, education level, and age. I found that some of these characteristics have ramifications for the findings of this study. For example, I argue that age might also be a determinant in these women's lower or higher fertility intentions. As is extensively stated in fertility literature, reproductive behavior is biologically constrained and delaying fertility has a negative impact on both fertility intention and outcome (see Philipov et al., 2009; Yang, 2017). This situation may particularly be the case for the women in the first group who might have considered that with a limited reproductive time ahead of them, and their existing family size, they have already reached the two-child norm prevalent in the country and may feel quite justified in forgoing the idea of having an additional child. Conversely, the women in the other two categories who are relatively younger and have lower fertility may feel an urge to reach the societal ideal family size of two children. Another relevant factor might concern different educational backgrounds these women have. An extensive research reports that educational differentials are among the best-established socioeconomic factors determining fertility decision-making, with research most widely stating that fertility aspirations are lower among the educated women (e.g., Bongaarts, 2003; Caldwell, 1982). In line with this research, I speculate that different educational backgrounds may at least partially account for the study women's different fertility aspirations independent of their gender roles. Naturally, both age and education can be closely interlinked with how gender roles are understood and considered. In line with this, interviews suggest that gender ideology may be more understood among the highly educated women and though it is a case for a small number of women, domestic gender equality may be more important in generating higher fertility intentions among the highly educated women. Moreover, women's attitudes change as they age and become mothers.

Overall, from the viewpoint of a gender egalitarian framework, similar to what Harriet Presser (1994) found in her work, this study, too, indicates that progression to gender equity in the domestic sphere is very slow. More specifically, the fact that a significant number of women in this study had a clear commitment to domestic gender equality, yet only a few achieved this state in their families demonstrates that Turkish women still have a long way to go to experience domestic equality. Moreover, in regard to fertility outcomes, the findings of this study indicate that women shouldering larger shares of housework and childcare seems to be an important 
reason for decreasing fertility in Turkey. The data showed that irrespective of their employment status, the women in this study spend far more time on domestic labour than their husbands do and when they received help through outsourcing, informal help, or equal sharing with the husband, they have a higher propensity to continue childbearing, which shows that reduced fertility is connected to women's domestic labour and that in the case of an equal division of labour, these women tend to increase their fertility. This finding is consistent with the gender revolution theory, which states that greater gender equality, both in the labour market and at home, with husbands' increased participation in the domestic sphere, is connected to higher fertility, especially in developed countries (Goldscheider et al., 2013; Goldscheider et al., 2015). However, judging from the fact that only a very small number of sampled women in this study enjoyed domestic equality with its positive implication for fertility intention, it is safe to suggest that the gender revolution is just evolving in this environment. Nevertheless, the findings of this study suggest that gender revolution theory is still relevant for the understanding of fertility patterns in this context.

This study has important contributions to the scholarship on the gender rolesfertility relationship. First of all, studying a Middle Eastern setting brings a nonWestern perspective to the research in this area. There is a paucity of research examining domestic gender equality and fertility in the Middle Eastern setting. In fact, no single study, to this date, has been carried out regarding the domestic gender equality and fertility relationship in this region, displaying a clear need to advance the research through exploring this link in different contexts with diverse gender norms and fertility trends. Moreover, it is also important to investigate to what extent the gender revolution framework is relevant in a different setting as diverse as the Middle East.

Secondly, using qualitative data helped analyze complexities that would have remained elusive in any quantitative work. For example, I distinguished between husband's help with household chores and a systematic and consistent division of labour in the family. The analysis of the data revealed that the notion of husband help does not entail women's commitment to egalitarian gender ideology, whereas women who consistently used the word iş bölümü (division of labour), particularly when they refer to housework sharing in their family, had a clearer adherence to the ideology of gender equity and correspondingly shaped their reproductive plans.

There are limitations to this research as well. The most relevant is that, since I do not have information about the husbands' self-report of their adherence of gender equity within the home, the analysis of the study might be biased by the fact that spouses differ in their reporting of housework share and gender attitudes. Moreover, a couple-level analysis could be ideal in fully capturing the gender-fertility relationship since maintenance of normative gender roles occurs in a couple's interaction processes within the family (Singley \& Hynes, 2005), which is also true for fertility decision-making. Finally, the findings from this small sample of mostly currently married and employed women should be viewed as exploratory and should not be generalized to the larger population. Future research should employ a large-scale dataset, perhaps survey data, for additional insight into this uncharted terrain in this region. 


\section{Abbreviations}

TDHS: Turkish demographic and health survey; Turkstat: Turkish statistical institute

\section{Acknowledgements}

Special thanks to Julie de Jong for her helpful comments and suggestions and to Fatima Faddlalla for her editorial help during the preparation of this article and to the Turkish respondents who provided the data for this research.

\section{Author's contributions}

The author read and approved the final manuscript.

\section{Funding}

The study was supported by a grant from the Scientific and Technological Research Council of Turkey (TUBITAK), Grant \#113 K073), an approval for the study was obtained from the Human Research Ethics Committee during the Grant application process. The funding source has no role in the design of the study and collection, analysis, and interpretation of data and in writing the manuscript.

\section{Availability of data and materials}

The qualitative data generated and analyzed during the current study are not publicly available in order to maintain respondents' confidentiality but are available from the corresponding author on reasonable request.

\section{Competing interests}

The author declares that she has no competing interests.

\section{Received: 14 December 2018 Accepted: 9 September 2019}

Published online: 16 October 2019

\section{References}

Aassve, A., Fuochi, G., Mencarini, L., \& Mendola, D. (2015). What is your couple type? Gender ideology, housework-sharing, and babies. Demographic Research, 32, 835-858.

Akadlı-Ergöçmen, B. (1997). An overview of women's status and fertility in Turkey. In M. E. Cosio-Zavala (Ed.), Women and families: Evolution of the status of women as factor and consequence of changes in family dynamics (pp. 79105). Paris: CICRED.

Ataca B., Kağı̆tçıbaşı Ç., Diri, A. (2005). The Turkish family and the value of children: trends over time. In: Nauck, B., \& Trommsdorff, G. (Eds). The value of children in cross-cultural perspective: Case studies from eight societies, (pp 91-120), Lengerich: PABST.

Aycan, Z. (2004). Key success factors for women in management in Turkey. Applied Psychology. An International Review, 53, 453-477.

Aycan, Z., \& Eskin, M. (2005). Relative contributions of childcare, spousal support, and organizational support in reducing work-family conflict for men and women: The case of Turkey. Sex Roles, 53, 453-471.

Becker, G. S. (1981). A treatise on the family. Cambridge: Harvard University Press,

Becker, G. S. (1985). Human capital, effort, and the sexual division of labor. Journal of Labor Economics, 3, 33-58.

Bianchi, S. M., Milkie, M. A., Sayer, L. C., \& Robinson, J. P. (2000). Is anyone doing the housework? U.S. trends in the gender division of household labor. Social Forces, 79, 191-228.

Bongaarts, J. (2003). Completing the fertility transition in the developing world: The role of educational differences and fertility preferences, policy research division working paper no. 177. New York: Population Council.

Brines, J. (1994). Economic dependency, gender, and the division of labor at home. American Journal of Sociology, $100,652-688$

Brinton, M. C., Bueno, X., Oláh, L., \& Hellum, M. (2018). Postindustrial fertility ideals, intentions, and gender inequality: A comparative qualitative analysis. Population and Development Review, 44, 281-309.

Brodmann, S., Esping-Andersen, G., \& Guell, M. (2007). When fertility is bargained: Second births in Denmark and Spain. European Sociological Review, 23, 599-613.

Caldwell, J. C. (1982). Theory of fertility decline. London: Academic.

Cavalli, L., \& Rosina, A. (2011). An analysis of reproductive intentions of Italian couples. Population Review, 50, 21-39.

Chafetz, J. S. (1988). The Gender Division of Labor and the Reproduction of Female Disadvantage. Journal of Family Issues, $9,108-31$.

Cherlin, A. J. (2016). A happy ending to a half-century of family change? Population and Development Review, 42, 121-129.

Cooke, L. P. (2009). Gender equity and fertility in Italy and Spain. Journal of Social Policy, 38, 123-140.

D'Addato, A. V., Vignoli, D., \& Yavuz, S. (2007). Towards smaller family size in Egypt, Morocco and Turkey: Overall change over time or socio-economic compositional effect?MPIDR working paper WP-2007-012. Rostock: Max Planck Institute for Demographic Research.

Dayioglu, M. (2000). Labor market participation of women in Turkey. In F. Acar \& A. Gunes-Ayata (Eds.), Gender and identity construction: Women of Central Asia, the Caucasus and Turkey. Leiden: Brill.

Dribe, M., \& Stanfors, M. (2009). Does parenthood strengthen a traditional household division of labor? Evidence from Sweden. Journal of Marriage and Family, 71, 33-45.

Duvander, A. Z., \& Andersson, G. (2006). Gender equality and fertility in Sweden. A study on the impact of the Father's uptake of parental leave on continued childbearing. Marriage \& Family Review, 39, 121-142.

Espenshade, T. J. (1972). The price of children and socioeconomic theories of fertility. Population Studies, 26, 207-221.

Esping-Andersen, G. (2009). The incomplete revolution: Adapting to Women's new roles. London: Polity Press.

Fikret-Pasa, S., Kabasakal, H., \& Bodur, M. (2001). Society, organizations, and leadership in Turkey. Applied Psychology. An International Review, 50, 559-589. 
Freeman, E., Xiaohong, M., Ping, Y., Wenshan, Y., \& Gietel-Basten, S. (2018). 'I couldn't hold the whole thing': The role of gender, individualisation and risk in shaping fertility preferences in Taiwan. Asian Population Studies, 14, 61-76.

Gershuny, J. (2000). Changing times: Work and leisure in postindustrial society. UK: Oxford University Press.

Goldscheider, F., Bernhardt, E., \& Branden, M. (2013). Domestic gender equality and childbearing in Sweden. Demographic Research, 29, 1097-1126.

Goldscheider, F., Bernhart, E., \& Lappegård, T. (2015). The gender revolution: A framework for understanding changing family and demographic behavior. Population and Development Review, 41, 207-239.

Gündüz-Hosgör, A., \& Smits, J. (2008). Variation in the employment status of women in Turkey. Women's Studies International Forum, 31, 104-117.

Harknett, K., Billari, F. C., \& Medalia, C. (2014). Do family support environments influence fertility? Evidence from 20 European countries. European Journal of Population, 30, 1-33.

Hazan, M., \& Zoabi, H. (2014). Do highly-educated women choose smaller families? The Economic Journal, 125, 1191-1226.

Hochschild, A. R., \& Machung, A. (1989). The second shift: Working parents and the revolution at home. New York: Viking.

Illkkaracan, I. (2012). Why so few women in the labor market in Turkey? Feminist Economics, 18, 1-37.

Kan, M., \& Hertog, E. (2017). Domestic division of labor and fertility preference in China, Japan, South Korea, and Taiwan. Demographic Research, 36, 557-588.

Kavas, S., \& Thornton, A. (2019). Developmental idealism and beliefs about marriage and fertility in Turkey. Population Research and Policy Review. https://doi.org/10.1007/s11113-019-09525-2.

Kim, E. H.-W. (2017). Division of domestic labour and the lowest-low fertility in South Korea. Demographic Research, $37,743-768$.

Koç, l., Türkyılmaz, A. S., \& Adalı, T. (2013). Fertility, Turkish Demographic and Health Survey-2013 Report. Ankara: Hacettepe Institute for Population Studies.

Lesthaeghe, R. (2010). The unfolding story of the second demographic transition. Population and Development Review, 36, 211-251.

Mason, K. O. (1986). The status of women: Conceptual and methodological issues in demographic studies. Sociological Forum, 1, 284-300.

Mason, K. O. (1997).Gender and Demographic Change: What do we know? In G.W. Jones et al. (Eds.), The Continuing Demographic Transition (pp. 158-182). Oxford: Clarendon Press.

Matthews, S. (2005). Crafting qualitative research articles on marriages and families. Journal of Marriage and Family, 67, 799-808.

McDonald, P. (2000a). Gender equity in theories of fertility transition. Population and Development Review, 26, 427-439.

McDonald, P. (2000b). Gender equity, social institutions and the future of fertility. Journal of the Australian Population Association, 17, 1-16.

Miettinen, A., Lassi, L., \& Rotkirch, A. (2015). Women's housework decreases fertility: Evidence from a longitudinal study among Finnish couples. Acta Sociologica, 58, 139-154.

Miller, W. B. (2011). Differences between fertility desires and intentions: Implications for theory, research and policy. Vienna Yearbook of Population Research, 9, 75-98.

Miller, W. B., Severy, L. J., \& Pasta, D. J. (2004). A framework for modeling fertility motivation in the dyad. Population Studies, $58,193-205$.

Mills, M., Mencarini, L., Tanturri, M.L., Begall, K. (2008). Gender equity and fertility intentions in Italy and the Netherlands. Demographic Research, 18, 1-26.

Nagase, N., \& Brinton, M. C. (2017). The gender division of labor and second births: Labor market institutions and fertility in Japan. Demographic Research, 36, 339-370.

Neyer, G., Lappegard, T., \& Vignoli, D. (2013). Gender equality and fertility: Which equality matters? European Journal of Population, 29, 245-272.

Oláh, L. S. (2003). Gendering fertility: Second births in Sweden and Hungary. Population Research and Policy Review, 22, 171-200.

Özbilgin, M., \& Healy, G. (2004). The gendered nature of career development of university professors: The case of Turkey. Journal of Vocational Behavior, 64, 358-371.

Philipov, D., Thévenon, O., Klobas, J., Bernardi, L., \& Liefbroer, A. (2009). Reproductive decision-making in a macro-micro perspective (REPRO): State-of-the-art review. Vienna: Institute of Demography, European Demographic Research papers No. 1.

Presser, H. B. (1994). Employment schedules among dual-earner spouses and the division of household labor by gender. American Sociological Review, 59, 348-364.

Puur, A., Oláh, L. S., Tazi-Preve, M. I., \& Dorbritz, J. (2008). Men's childbearing desires and views of the male role in Europe at the dawn of the 21st century. Demographic Research, 19, 1883-1912.

Randall, S., \& Koppenhaver, T. (2004). Qualitative data in demography: The sound of silence and other problems. Demographic Research, 11, 57-93.

Raz-Yurovich, L. (2016). Outsourcing of housework and the transition to a second birth in Germany. Population Research and Policy Review, 35, 401-417.

Sanchez, L., \& Thomson, E. (1997). Becoming mothers and fathers: Parenthood, gender, and the division of labor. Gender \& Society, $11,747-772$.

Schoen, R., Young, J. K., Constance, A. N., Fields, J., \& Astone, N. (1997). Why do Americans want children? Population and Development Review, 23, 333-358.

Singley, S. G., \& Hynes, K. (2005). Transitions to parenthood: Work-family policies, gender, and the couple context. Gender \& Society, 19, 376-397.

Strauss, A., \& Corbin, J. (2015). Basics of qualitative research: Techniques and procedures for developing grounded theory. London: Sage.

Tazi-Preve, M. I., Bichlbauer, D., \& Goujon, A. (2004). Gender trouble and its impact on fertility intentions. Yearbook of Population Research in Finland, 40, 5-24.

Torr, B. M., \& Short, S. E. (2004). Second births and the second shift: A research note on gender equity and fertility. Population and Development Review, 30, 109-130. 
Turkish Demographic and Health Survey (TDHS). (2013). Demographic transition in Turkey. Ankara: Hacettepe University Institute of Population Studies http://www.hips.hacettepe.edu.tr Accessed 17 Sep 2016.

Turkish Statistical Institute (Turkstat). (2016). Family structure survey http://www.turkstat.gov.tr/UstMenu.do?metod=temelist Accessed 15 Nov 2016.

Turkish Statistical Institute (Turkstat). (2018). Population statistics http://www.turkstat.gov.tr/UstMenu.do?metod=temelist Accessed 15 Sep 2018

Uysal-Kolaşin, G., Paker-Uncu, Z. H., Cansuz, Y., \& Kökkızıl, M. (2015). Türkiye'de Lise ve Üniversite Mezunu Kadınların İşgücüne Katılım Kararlarının Incelenmesi, survey report http://betam.bahcesehir.edu.tr.

Yang, J. (2017). Gendered division of domestic work and willingness to have more children in China. Demographic Research, 37, 1949-1974.

Yavuz, S. (2006). Completing the fertility transition: Third birth developments by language groups in Turkey. Demographic Research, 15, 435-460.

Yoon, S. Y. (2017). The influence of a supportive environment for families on women's fertility intentions and behavior in South Korea. Demographic Research, 36, 227-254.

\section{Publisher's Note}

Springer Nature remains neutral with regard to jurisdictional claims in published maps and institutional affiliations.

Submit your manuscript to a SpringerOpen ${ }^{\circ}$ journal and benefit from:

- Convenient online submission

- Rigorous peer review

- Open access: articles freely available online

- High visibility within the field

- Retaining the copyright to your article 